\title{
Estendendo o conceito de cadência para 0 repertório pós-tonal
}

\author{
Antenor Ferreira Corrêa (UnB, Brasília, DF) \\ antenorfc@unb.br
}

\begin{abstract}
Resumo: Toma-se o conceito de cadência, tópico do campo da harmonia, com um duplo objetivo: refletir sobre o uso da terminologia musical, expondo certa falta de consenso observada entre autores brasileiros, e exemplificar a permanência do conceito de "cadência" no repertório pós-tonal. Inicia-se com uma revisão histórico/conceitual do tema, investigando como esse assunto é tratado em livros selecionados, seus pontos de contato e divergência, sugerindo, ao final, uma abordagem para a classificação das progressões acórdicas. A seguir, partindo desses entendimentos, intenta-se estender a ideia de função cadencial para o repertório não-tonal, exemplificada com progressões conclusivas e de artifícios de tonicização em obras do século XX.
\end{abstract}

Palavras-chave: cadências em música; terminologia musical; harmonia; análise musical; pós-tonalidade.

\section{Extending the concept of cadence to the post-tonal repertoire}

Abstract: This paper concerns with the notion of cadence, issue more related to harmony, but taken here under double aim: to reflect about the use of musical terminology (pointing out the lack of consensus among Brazilian authors), and to exemplify as the concept of cadence still remains active in post-tonal repertoire. Firstly, a historical review of the theme is presented, surveying how it is dealt in selected books, showing similar and conflicting points. Moreover, a classificatory approach to the effects of tension and relief inherent at chord progressions is suggested. Secondly, based on these understandings, the extension of the idea of cadential function to non-tonal repertoire is proposed, which is illustrated with conclusive progressions and tonicizing devices from musical works of the twentieth-century repertoire.

Keywords: music cadence; musical terminology; harmony; musical analysis; post-tonality.

\section{1 - Sobre a terminologia musical}

A comparação entre as definições fornecidas para alguns tópicos na literatura musical revelará aos leitores mais atentos uma grande falta de consenso. Esse babelismo é gerado pela discordância entre os autores não só em relação ao entendimento que cada qual tem sobre os conceitos que se propõem a explicar, mas também pelas diferentes terminologias que empregam. Resultam daí significativas divergências, pois noções básicas adquirem diferentes definições, por vezes, controversas e conflitantes entre si, ao passo que distintas significações são atribuídas a um mesmo termo. Quando se transporta essa tarefa da biblioteca para a sala de aula, isto é, se esse tipo de comparação for realizado no âmbito da docência, a situação não melhora. Pode-se observar que os professores tendem a adotar conceitos e terminologias em razão de suas distintas formações. Docentes formados ou ligados de alguma maneira à metodologia francesa, por exemplo, tendem a aplicá-la em classe. Situação similar ocorre com os afeitos às literaturas norte-americana, italiana ou alemã.

Essa falta de consenso ou, em alguns casos, de refinamento teórico, além de provocar deficiências educacionais, dificulta o trabalho dos pesquisadores (sobretudo, aqueles de outras áreas de estudo que, por quaisquer motivos, têm que se dedicar a questões musicais). É comum, infelizmente mesmo entre músicos formados, o uso incorreto da terminologia musical. Não raro se ouve a pergunta: qual o tom dessa música? Trocando-se, assim, o termo tonalidade por tom. Do mesmo modo, observa-se o equívoco na questão: qual a tônica desse acorde? Empregando-se, a palavra tônica no lugar de fundamental do acorde. Nesse sentido, encontram-se nos livros enunciados controversos, como por exemplo: "qual a tonalidade da tônica dessa peça?" (BENNETT, 1986, p.20 e passim). 
Quando se trata de palavras estrangeiras traduzidas para o português nota-se a mesma diversidade, pois termos e expressões são versados livremente de acordo com o gosto ou entendimento do autor que realiza a tradução, muitas vezes gerando duplicações desnecessárias. Essa característica é fortemente notada no campo da harmonia musical. Nos encadeamentos harmônicos duas palavras em inglês crossing e overlaping muitas vezes são usadas em português com o mesmo sentido, isto é, para indicar cruzamento de vozes, quando na verdade tratam-se de dois aspectos diferentes das normas para condução das vozes. Obviamente, nem todo termo precisa ou pode de fato ser traduzido diretamente, vale lembrar que palavras em italiano têm sido usadas no repertório musical há tempos, encontrando-se incorporadas ao cotidiano dos músicos, uma vez que o italiano constituise como uma espécie de idioma oficial da música, sobretudo sinfônica. Porém, termos e designações que possuam um correspondente mais funcional em nosso idioma, na medida em que contribuam para evitar malentendimentos e favorecer 0 aprendizado, poderiam receber traduções unificadas.

Adentrando ao século $X X$ é possivel identificar circunstânciasnasquais persistea mesma desconformidade entre autores ao lado de outras situações que aguardam por teorizações consistentes. 0 procedimento usado por Debussy de suceder acordes paralelamente, nomeado em inglês como planing, por não possuir um termo correspondente em português, é traduzido como paralelismo. Porém, o termo planing, também sinônimo de parallelism (veja KOSTKA \& PAYNE, 2000, p.511), é preferido na literatura norte-americana justamente por não aludir à herança harmônica tradicional, cujas regras preconizam ser o paralelismo um procedimento a ser evitado. 0 que faz pensar se em português também não deveriamos propor um termo correlato para esse procedimento. Alguns autores também propõem a diferenciação entre harmonia quartal e harmonia por quartas. Essas seriam distinguidas pelo contexto no qual se inserem, isto é, em um ambiente tonal é possivel a construção de acordes por sobreposição de intervalos de quartas, posto que os acordes preservam sua identidade quando colocados em inversão; assim, uma formação como $A-D-G-C-F \#$ poderia ser interpretada como um acorde de $D 7 / 11$ em segunda inversão. A harmonia quartal implica em um domínio não tonal, referindo-se ao uso de intervalos de quartas (justas e/ou aumentadas) como base para a construção das entidades harmônicas (veja PERSICHETTI (1961), SCHOENBERG (2001) e KOSTKA \& PAYNE (2000)). Similarmente, há novos termos de uso corrente na linguagem falada que ainda não aparecem nos livros como, por exemplo, gesto, algoritmo, tempo liso e tempo estriado, entre outros.

Partindo dessa linha de pensamento, isto é, a análise do uso da terminologia musical e o repertório pós-tonal, neste trabalho atenho-me a um tópico do campo da harmonia que explicita essa situação de "dissonância" entre autores: cadência. Inicio com uma espécie de revisão histórico/conceitual sobre o tema, investigando como esse assunto é tratado em alguns livros, seus pontos de contato e divergência, sugerindo, ao final, uma abordagem para a classificação dessas progressões acórdicas. A seguir, partindo desses entendimentos, intento estender a ideia de "cadência" para o repertório pós-tonal, exemplificando a permanência desse conceito por meio do emprego de progressões conclusivas e uso de tonicizações em obras do século XX.

\section{2 - Sobre cadências}

A progressão ou sucessão de acordes que conduzem uma frase musical a uma conclusão é chamada de cadência. Etimologicamente, cadência provém do latim cadentia, particípio cadere, significando cair (mesma raiz da palavra cadente, donde se tem a expressão estrela cadente). A proveniência latina é verificada em vários idiomas tais como: espanhol: cadencia, francês: cadence; italiano cadenza; alemão: kadenz, inglês: cadence, indicando uma raiz comum entre eles.

É interessante notar que em música cadência pode remeter, além da citada progressão de acordes, à ideia de ritmo ou andamento, por exemplo, quando se diz "uma marcha cadenciada" ou "a cadência do samba". 0 momento solístico de um concerto é também chamado de cadência, indicando inclusive a parte escrita para esse momento solo, tornando usuais assertivas do tipo: "a cadência do concerto para violino é de extremo virtuosismo". Desses três usos verificados para o termo, seria correto indagar 0 que compartilham com a acepção latina original da palavra (cair) que os permitem ser reduzidos a um denominador comum, fazendo com que uma palavra passe a designar três coisas aparentemente distintas.

É preciso lembrar que bem antes do uso pela Harmonia, cadência designava na literatura e na poesia o fluxo ou ritmo dos versos (de um poema, por exemplo). Como artifício retórico, o declamador, ao chegar ao final de um verso, usava modular sua inflexão vocal para um registro mais grave, dando assim o sentido de queda da entonação $e$, consequentemente, de finalização daquela frase. Essa mudança de inflexão da voz recebia também o nome de cláusula, designando o final de um periodo linguístico no qual os escritores intensificavam os efeitos rítmicos. A quantidade de sílabas nos versos era a base sobre a qual uma sequência métrica regular estabelecia-se e as palavras finais de um texto (poema ou discurso) quedavam-se como um componente contumaz da efetividade retórica. Em música, desde sempre associada ao texto, a ideia de queda melódica foi mantida e associada, também, a modificações rítmicas, como hemíolas e variações agógicas, de modo a enfatizar o fechamento das frases textuais, recebendo primeiramente a denominação de cláusula (o desfecho rítmico-melódico de uma sentença) e, posteriormente, cadência. Nessa correspondência entre o fechamento textual e as transformações melódicas e rítmicas, 
quando a finalização rítmico-melódica concordava com a prosódia textual, fazendo coincidir o tempo forte do compasso com a sílaba tônica do texto, dava-se uma terminação masculina, do contrário, se a conclusão ocorresse em tempo fraco do compasso, dizia-se terminação feminina ${ }^{1}$. Com isso, os dois usos do termo cadência em música, acima mencionados, podem ser remetidos ao domínio das artes da palavra, denotando tanto o aspecto rítmico quanto o de conclusão melódica, dai a ideia de repouso. Justamente por isso, o movimento cadencial é entendido como uma tensão que conduz a um fechamento onde essa tensão é desfeita, distendida.

0 emprego do termo para designar a passagem solista do concerto, embora apartado do sentido de cair, também deriva do entendimento de cadência enquanto finalização de frase. Foi usual durante os periodos renascentista e barroco deixar a cargo do intérprete um grupo de notas, ou uma pequena passagem ornamental, próxima do final de uma canção. Essa finalização não possuía valores rítmicos estabelecidos pelo compositor, tendo assim a intenção de criar um momento particular de expressão do intérprete, que finalizava aquela passagem de acordo com sua sensibilidade. Na música instrumental, a partir do século XVIII, cadenza ou passagem de bravura designava o momento solístico introduzido perto do final de um movimento, servindo como uma espécie de apoteose, dado o caráter virtuosístico que comportava. De acordo com a Enciclopédia Britânica ${ }^{2}$ até bem perto de finais do século XIX, tais passagens interpoladas eram, muitas vezes, improvisadas pelo intérprete em momentos prédeterminados pelo compositor. A cadenza não pretendia exibir somente a habilidade ou perícia técnica, mas, também, o grau de espontaneidade e inventividade do executante. Posteriormente, esses momentos passaram a ser escritos pelo compositor. 0 solo de oboé no primeiro movimento da Sinfonia $n^{\circ} 5$ de Beethoven é um exemplo desse tipo de cadência. Savino De Benedictis lembra que recebia o nome de "'Cadência de Bravura uma suspensão de andamento no centro, ou no final de uma composição, onde há um variado grupo de notas, sem medida determinada. Serve para por em evidência a bravura do executor" (BENEDICTIS, 1970, p.29). Desse modo, um procedimento restrito a algumas poucas notas de final de frase foi estendido de maneira a vir a tornar-se uma parte independente da obra. Assim, se justifica o emprego do conceito de cadência para referir-se ao momento solista da obra, já que provém do antigo emprego enquanto finalização de frase.

Embora cadência remeta diretamente às progressões acórdicas envolvidas na finalização de frases musicais, sucessões essas, por sua vez, mais próprias da textura homofônica, é possivel retroceder sua aplicação às práticas de conclusão de frases na música polifônica denominadas cláusulas ${ }^{3}$ ou occursus. Guido d'arezzo no seu Micrologus de Disciplina Artis Musicae ${ }^{4}$ (Tratado Sucinto na Disciplina da Arte Musical, cerca de 1026) foi um dos primeiros a teorizar sobre o assunto. Esse tratado era destinado ao ensino dos cantores, envolvendo aspectos como o organum ou o canto a duas ou mais vozes. Nesse tópico, D'Arezzo descreve o occursus (literalmente: encontro) como a maneira de finalização de uma frase musical em uma textura polifônica a duas vozes, na qual as linhas convergem para o uníssono. A cláusula era uma espécie de cadência intervalar baseada em diades, mas não em acordes. Uma cláusula implica em duas vozes que caminham por movimento contrário em direção à mesma nota (seja essa um uníssono ou em distância de oitava). Quando essas cláusulas passaram a ser ornamentadas antes da conclusão sobre a nota principal do modo, receberam também outras denominações. Uma das mais conhecidas é a ornamentação do tipo escapada, descendo uma terça a partir da nota da cláusula e resolvendo na finalis do modo, procedimento que ficou conhecido como "cadência de Landini", vide Ex.1.

A música polifônica renascentista empregava fórmulas cadenciais semelhantes às medievais, porém, em obras a mais de duas vozes, essas eram adaptadas para sua sonoridade característica, ou seja, substituindo as consonâncias perfeitas pelas imperfeitas. Assim, as sensiveis superior e inferior presentes nas fórmulas cadenciais da música medieval continuavam mantidas no repertório renascentista, mas a nota interior a essas sensíveis externas era

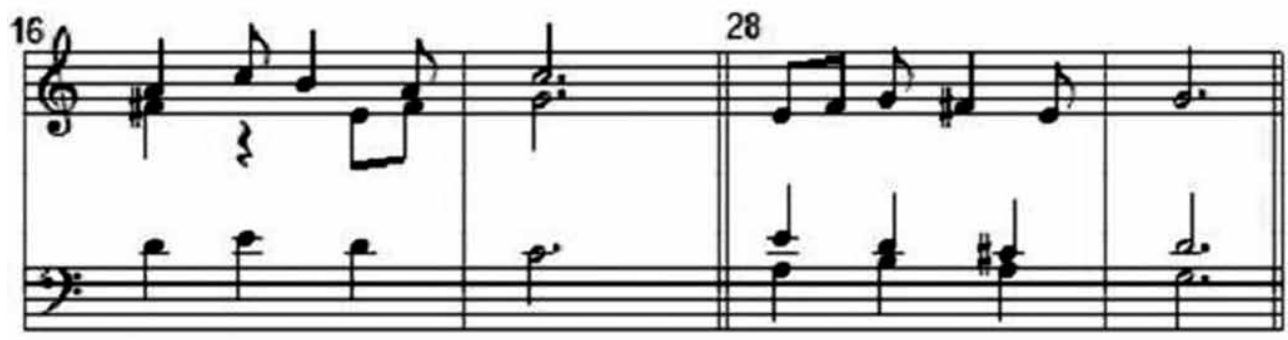

Ex.1 - Francesco Landini, ballata Non avrà ma pietà (c.16-17 e 28-29): Cadência de Landini 
modificada de modo a finalizar a frase com a terça no lugar da quinta. No Ex.2 estão descritas duas fórmulas cadencias, a primeira típica da música medieval (Ex.2a) chamada de cadência de dupla sensivel, e a segunda característica da polifonia renascentista (Ex.2b). "As cadências geralmente ocorriam no final de cada frase do texto e eram marcadas pela resolução da sensível em uma voz, enquanto a outra voz descendia para formar um uníssono ou oitava com a primeira. (...) Essa foi a fórmula cadencial mais comum no século XVI" (OWEN, 1992, p.30).

Não obstante o emprego de cadências desde a Idade Média, foi na literatura sobre harmonia que essas sucessões de acordes que conduzem a frase ao seu fechamento tornaram-se objetos de intensa sistematização. Com isso, essas progressões receberam diversas denominações por parte dos diferentes autores que se propuseram delas discutir. Já no primeiro tratado de harmonia, Rameau lançou as designações perfeita, deceptiva e irregular para classificar os movimentos cadenciais. Segundo ele, a cadência perfeita ascende uma quarta justa ou descende uma quinta justa (vide Ex.3a). Uma cadência deceptiva ocorre quando a resolução de algum dos sons da cadência perfeita é modificada (Ex.3b). A cadência irregular designa para Rameau o movimento da tônica para a dominante (Ex.3c e $3 d$ ).
Durante a história da música, os compositores criaram novas fórmulas cadenciais e aplicaram um uso renovado das cadências clássicas. Com isso, nas publicações que se seguiram, cada autor acabou por propor uma nova maneira de explicar e classificar essas fórmulas, gerando assim novos entendimentos, terminologias e uma pletora de subgrupos classificatórios. A seguir, algumas dessas sistematizações são consideradas, iniciando com a comparação entre títulos publicados em português (originais e traduções).

João Sépe (1942) classificou as cadências em dois grupos: conclusivas e suspensivas. No interior do primeiro grupo situou as cadências: autêntica ou perfeita ( $\mathrm{V}$-I estando ambos acordes em posição fundamental e a nota mais aguda do I deve ser seu primeiro grau), plagal (IV-I) e composta (IV-V-I). No segundo grupo compreendeu as cadências: imperfeita (quando se dá a resolução do acorde de dominante sobre a primeira inversão do acorde de tônica e vice-versa, ver Ex.4a), de engano ou interrompida ( $\mathrm{V}-\mathrm{VI}$ ou $\mathrm{V}-\mathrm{X}$ sendo $\mathrm{X}$ qualquer acorde que não o de tônica), semi-cadência antiga (I-IV, ver Ex.4b) e evitada (quando se dá a terminação de um membro de frase sobre um acorde modulante. Ver Ex.4c). 0 uso dessas denominações mostra a filiação de Sépe com o uso da nomenclatura de tradição francesa (vide adiante os termos utilizados por DANHAUSER).

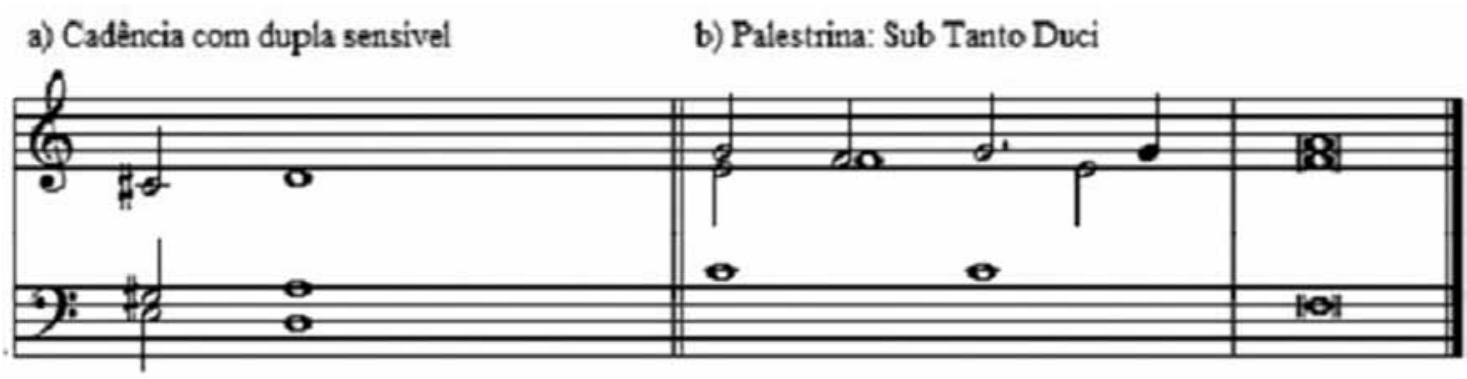

Ex.2 - (a) Resolução cadencial com dupla sensivel em 'acorde' aberto. (b) Final de Sub Tanto Duci de Palestrina, resolução em 'acorde' com terça.

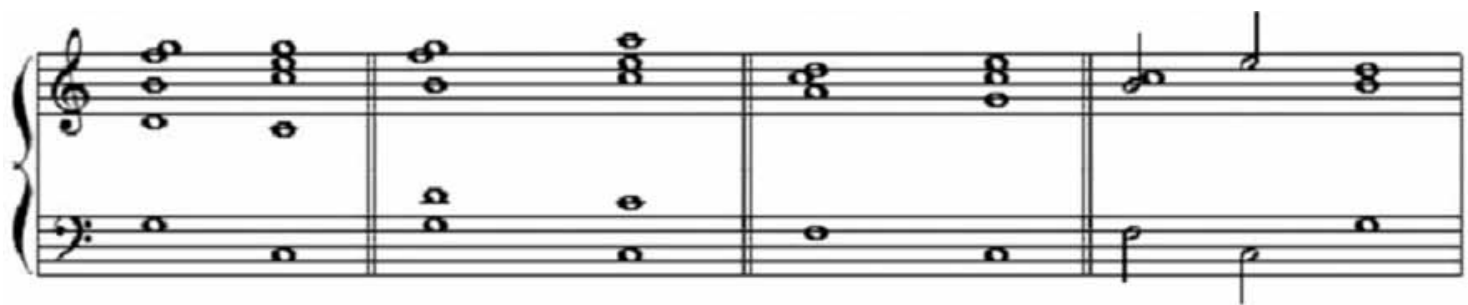

Ex.3 - Progressões cadenciais em Rameau: cadências: perfeita $(a)$, deceptiva $(b)$ e irregular (c e $d$ ). 


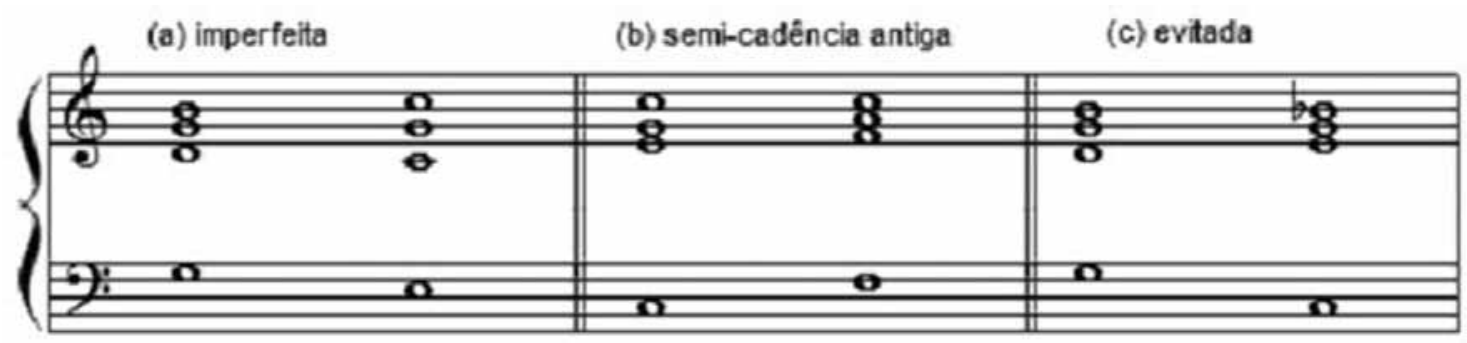

Ex.4 - Classificações cadenciais em Sépe: (a) imperfeita, (b) semi-cadência antiga, (c) evitada.

Hindemith não usa a denominação autêntica, perfeita ou imperfeita, mas considera as cadências de acordo com sua propriedade decisiva, assim, "cadências mais decisivas são aquelas em que o acorde da dominante precede ao da tônica" (veja HINDEMITH, p.101). No caso do acorde da subdominante preceder o da tônica, a cadência será plagal. Se o objetivo da cadência não for a tônica, mas a dominante, a cadência é classificada como semi-cadência.

No livro original de Cyro Brisolla não há uma sistematização explícita das progressões cadenciais, estas devem ser deduzidas no decorrer do texto. Ele deixa claro o que chama de cadência completa (S - D - T), ou seja, a progressão subdominante - dominante - tônica (veja 1979, p.87). Em outro momento vale-se da expressão cadência interrompida sugerindo o emprego do acorde de tônica invertido: "caso a nova tônica seja alcançada antes de ter surgido a subdominante usa-se, em lugar daquela, a cadência interrompida, a qual se segue com a completa" (BRISOLLA, 1979, p.88). Talvez em razão dessa não classificação das cadências, Mario Ficarelli sentiu a necessidade de ampliar o livro de Brisolla quando de sua segunda edição. Adicionou, então, a essa nova publicação, um apêndice no qual classifica os movimentos cadenciais da seguinte maneira (veja BRISOLLA, 2006, p.97-100):

- Cadência autêntica: tônica precedida pela dominante;

- Plagal: tônica precedida pela subdominante;

- De engano: sequência direcionada para a tônica, todavia, no lugar desta usa-se a tônica com a terça no baixo;

- Interrompida, evitada ou deceptiva: sequência direcionada para a tônica; todavia, no lugar desta usa-se qualquer outro acorde que não o de tônica;

- $\quad$ Frígia ou semi-cadência: cadência cujo objetivo não é a tônica, mas sim a dominante.

Também dirigido ao ensino da harmonia funcional, o livro de José Zula De Oliveira divide em dois grupos os movimentos cadenciais: cadências principais e secundárias, trazendo, então, a seguinte classificação para o primeiro grupo (veja OLIVEIRA, 1978, pp.24-26):

Autêntica: T - D - T;

Plagal: T - S - T;

Perfeita (composta, mista ou completa): T - S - D - T.

Para o segundo grupo se dá a seguinte classificação:

Imperfeita: T - D (estando a dominante necessariamente em tempo fraco) e, também, a sequência $D-T$ ou $S-T$ (encontrando-se a tônica, nesses casos, necessariamente invertida);

Semi-cadência: T - D ou S - D;

De engano (evitada, interrompida, quebrada): qualquer resolução da $\mathrm{D}$ que não seja sobre a $\mathrm{T}$.

Finalizando essa breve incursão sobre alguns livros em língua portuguesa tem-se em Bennett a sistematização de quatro grupos cadenciais (Veja BENNET, 1986, p.1112):

Cadência perfeita: $\mathrm{V}-\mathrm{I}$;

Cadência plagal: IV - I;

Cadência imperfeita: qualquer acorde direcionado para a dominante como em I - V;

Cadência interrompida (ou de engano): dominante seguida por qualquer outro acorde que não o de tônica, como em V - VI.

Neste ponto já é possível observar, com essa curta seleção de textos, a citada falta de consenso entre os autores. Outro aspecto curioso é o fato de nenhum dos autores citados aludirem à herança modal implícita na nomenclatura que classifica as cadências do tipo V-I como autênticas e IV-I como plagais. É clara a proveniência desses termos ao sistema de classificação dos modos eclesiásticos, agrupados em autênticos (ou principais) e plagais (colaterais), estes se situando 
uma quarta justa abaixo daqueles. Adiante, serão consideradas algumas propostas de sistematização extraídas de títulos internacionais que até agora não possuem traduções para o português.

Walter Piston (Armonia, edição espanhola de 1998), de maneira similar a alguns autores já mencionados, explicou a cadência perfeita como a progressão que vai da dominante para a tônica, encontrando-se ambos os acordes em posição fundamental e sendo as notas extremas do acorde de tônica o seu primeiro grau. Se a finalização ocorresse sobre o acorde de tônica invertido ou com qualquer nota na voz superior que não o primeiro grau, dava-se a cadência imperfeita, entendida como uma fórmula cadencial menos conclusiva que a perfeita e pressupondo continuação. Piston também introduziu o que chamou de cadência autêntica ampliada (veja 1998, p.165), na qual estariam agrupadas as seguintes progressões:

$\mathrm{II}-\mathrm{V}-\mathrm{I} ; \mathrm{IV}-\mathrm{V}-\mathrm{I} ; \mathrm{V} / \mathrm{V}-\mathrm{V}-\mathrm{I} ; \mathrm{I}-\mathrm{V} / \mathrm{V}-\mathrm{V}-\mathrm{I}$; IV - V6/4=5/3 - I; II - V6/4=5/3- I

Uma cadência autêntica seguida de qualquer outro acorde que não o de tônica é chamada por Piston de cadência interrompida (veja 1998, p.174). Ele também explanou sobre as cadências à dominante (veja 1998, p.168), sendo essas: semi-cadência (por exemplo: V/V V) e a cadência frígia (IV6 - V no modo menor). Introduziu, ainda, o que denominou como tipos excepcionais de cadências (veja 1998, p.177), entendidas como variações das cadências plagal e frígia. Assim, tem-se:

I - VI6 - I

II6 - I variações da cadência plagal

(napolitana, pois Piston não usa grafar bll )

IV6 - V7

variação da cadência frigia

$\mathrm{Na}$ literatura francesa, grosso modo, é encontrada a seguinte classificação (cf., por exemplo: DOUÉ, 2005 e DANHAUSER, 1996, p.132-134):

Cadência perfeita: V - I (com ambos os acordes em posição fundamental);

Semi-cadência ou repouso sobre a dominante: $X-V$

Cadência imperfeita: V - I (com algum, ou ambos, acorde(s) invertido(s));

Cadência plagal: IV - I

Cadência quebrada [rompue]: V - VI

Cadência evitada (ou modulante): "quando o encadeamento de acordes de uma cadência quebrada implica necessariamente em uma mudança de tonalidade, esta recebe o nome de cadência evitada ou modulante" (DANHAUSER, 1996, p.133).

Cadência de picardia: conclusão sobre tônica maior de uma peça em tonalidade menor.
Considerem-se, a seguir, as sistematizações propostas em duas publicações, de certa forma recentes, de autores norte americanos: Kostka \&t Payne E Douglass Green.

Em Douglass Green (1965) há a seguinte classificação:

Cadência autêntica: V - I;

Cadência autêntica perfeita: $\mathrm{V}$ - I com ambos os acordes em posição fundamental e vozes extremas do I na tônica; Cadência autêntica imperfeita: qualquer cadência autêntica que não seja uma cadência perfeita;

Sem-cadência: "é a cadência que pode encerrar uma frase dentro da composição, porém não é conclusiva. Pode tomar várias formas, a mais comum é aquela na qual a progressão acórdica termina no V. Entretanto, outros tipos de semi-cadência surgem ocasionalmente, tais como os que terminam no IV ou I na primeira inversão" (GREEN, 1965, p.14);

Cadência deceptiva: tipo especial de semi-cadência onde o $\mathrm{V}$ é seguido por qualquer acorde que não o de I; Cadência completa: uma cadência autêntica ampliada por um acorde precedente ao V.

Por fim, em Kostka e Payne tem-se a seguinte classificação para as cadências:

Autêntica: tônica (I ou i) precedida pela dominante (V) ou sensivel $\left(\mathrm{vii}^{\circ}\right)$;

Autêntica perfeita: V - I ou V7 - I (ambos os acordes em posição fundamental e vozes extremas do I na tônica);

Autêntica imperfeita: qualquer cadência autêntica que não seja uma cadência perfeita. Por exemplo, V - I estando a voz mais aguda do I no terceiro ou quinto graus;

Autêntica invertida: V7 - I estando um destes acordes, ou ambos, invertidos;

Cadência de Sensível: quando o acorde de dominante (V) é substituído pelo acorde diminuto $\left(\mathrm{vii}^{\circ}\right)$;

Deceptiva: $\mathrm{V}$ - X (sendo $\mathrm{X}$ qualquer acorde que não 0 de tônica);

Semi-cadência: cadência para a dominante $(V)$ precedida por qualquer outro acorde;

Plagal: IV - I;

Cadência frígia: iv6 - V (trata-se de uma semi-cadência típica do modo menor).

A partir dessas descrições sumárias, envolvendo 0 entendimento e modo de explanação desses autores, é possível realizar uma comparação entre os sistemas classificatórios adotados avaliando a aplicabilidade e atualidade de cada proposta. Observe-se o quadro comparativo entre os autores e suas respectivas nomenclaturas: 


\begin{tabular}{|c|c|c|c|c|c|c|c|c|c|}
\hline \multirow{2}{*}{$\begin{array}{l}\text { Tipos de } \\
\text { Cadências }\end{array}$} & \multicolumn{9}{|c|}{ Autores } \\
\hline & Rameau & Sépe & Ficarelli & $\begin{array}{l}\text { Zula de } \\
\text { Oliveira }\end{array}$ & Bennett & Piston & Green & Danhauser & $\begin{array}{c}\text { Kostka \& } \\
\text { Payne }\end{array}$ \\
\hline Autêntica & & V-I & V-I & $|-V-|$ & & & V-I & & $\begin{array}{l}\text { V-I, V-i, } \\
\text { vii }{ }^{\circ}-\mathrm{I} e \\
\text { vii }^{\circ}-\mathrm{i}\end{array}$ \\
\hline Perfeita & V-I & $V-I^{*}$ & & I-IV-V-I & V-I & V-I & $V-I^{*}$ & $V-I^{*}$ & $\begin{array}{c}\text { V-I* ou } \\
\text { V7-I* }\end{array}$ \\
\hline Imperfeita & & $V-16$ & & $\begin{array}{l}\text { I-V ou } \\
\text { V-I6 }\end{array}$ & $X-V$ & & $* * *$ & $\begin{array}{c}\text { V-I } \\
\text { (um ou } \\
\text { ambos } \\
\text { acordes } \\
\text { invertidos) }\end{array}$ & $* * *$ \\
\hline Plagal & & IV-I & IV-I & I-IV-I & IV-I & IV-I & IV-I & IV-I & IV-I \\
\hline $\begin{array}{l}\text { Semi- } \\
\text { cadência }\end{array}$ & & $\begin{array}{c}\text { I-IV } \\
\text { antiga }\end{array}$ & $X-V$ & $\begin{array}{l}\text { I-V ou } \\
\text { IV-V }\end{array}$ & & $\begin{array}{l}\text { X-V } \\
\text { p.ex: } \\
\text { V/V-V }\end{array}$ & $\begin{array}{l}X-V \\
X-1 V \\
X-16\end{array}$ & $\begin{array}{c}\text { X-V } \\
\text { (sendo V, } \\
\text { obrigato- } \\
\text { riamente, } \\
\text { acorde de } \\
\text { dominante) }\end{array}$ & $X-V$ \\
\hline Frígia & & & $X-V$ & & & IV6 - V & & & iv6 - V \\
\hline Deceptiva & V-VI6 & & $V-X^{* *}$ & & & & $V-X^{* *}$ & & $V-X^{* *}$ \\
\hline Interrompida & & $V-X^{* *}$ & $\begin{array}{l}\text { V-X** e } \\
\text { V-I6 } \\
\text { (em } \\
\text { Brisolla) }\end{array}$ & $V-X^{* *}$ & $V-X^{* *}$ & $V-X^{* *}$ & & & \\
\hline Irregular & $\mathrm{I}-\mathrm{V}$ & & & & & & & & \\
\hline $\begin{array}{l}\text { Quebrada } \\
\text { [rompue] }\end{array}$ & & & & & & & & $V-V I$ & \\
\hline $\begin{array}{c}\text { Evitada } \\
\text { (ou } \\
\text { modulante) }\end{array}$ & & $V-17$ & $V-X^{* *}$ & $V-X^{* *}$ & & & & $\begin{array}{c}\text { V-VI } \\
\text { implicando } \\
\text { em } \\
\text { modulação }\end{array}$ & \\
\hline De engano & & $V-X^{* *}$ & V-16 & $V-X^{* *}$ & $V-X^{* *}$ & & & & \\
\hline Composta & & IV-V-I & & I-IV-V-I & & & & & \\
\hline $\begin{array}{l}\text { Autêntica } \\
\text { ampliada }\end{array}$ & & & & & & $\begin{array}{l}\text { II-V-I, } \\
\text { IV-V-I, } \\
\text { V/V-V-I } \\
\text { Etc. }\end{array}$ & & & \\
\hline Completa & & & $\begin{array}{l}\text { IV-V-I } \\
\text { (em } \\
\text { Brisolla) }\end{array}$ & & & & $X-V-I$ & & \\
\hline $\begin{array}{l}\text { Autêntica } \\
\text { invertida }\end{array}$ & & & & & & & & & $\begin{array}{c}\text { V7-I } \\
\text { (um ou } \\
\text { ambos } \\
\text { acordes } \\
\text { invertidos) }\end{array}$ \\
\hline De sensivel & & & & & & & & & vii ${ }^{\circ}$ I \\
\hline De picardia & & & & & & & & $\begin{array}{l}\text { T maior em } \\
\text { peça menor }\end{array}$ & \\
\hline
\end{tabular}

* autores observam que os acordes de V e I devem estar em posição fundamental e as vozes extremas do I devem ser o primeiro grau da tônica.

** sendo X qualquer acorde que não o de tônica.

*** definida como qualquer cadência autêntica que não seja uma cadência perfeita. Por exemplo, V - I estando a voz mais aguda do I no terceiro ou quinto graus. 
Pelo exposto anteriormente e por meio do quadro comparativo, observa-se que os autores divergem quanto à terminologia (usando diferentes termos para designar progressões similares) e quanto ao entendimento (designando com a mesma nomenclatura progressões distintas). Nota-se também certo consenso sobre a cadência plagal. Talvez o leitor tenha notado ausência de menção ao livro Harmonia de Schoenberg, todavia, as considerações sobre o modelo por ele proposto serão objeto de análise no próximo tópico deste artigo.

Da leitura desses textos foi possível notar, também, que a maioria dos títulos sobre harmonia coloca os aspectos práticos em primeiro plano. Com isso, há um privilégio para a realização de exercícios de encadeamento, o que é positivo por um lado (já que a maior parte do aprendizado da harmonia decorre da exercitação prática), no entanto, muitas vezes acaba por acarretar certa falta de aprofundamento nos tópicos apresentados. Por exemplo, explicações sobre a cadência frígia mostram apenas a realização de encadeamento empregando esse movimento cadencial. Não encontrei, na bibliografia em português, alguma explicação sobre a procedência da mesma ou sobre o porquê do uso desse nome para designá-la.

A propósito, sobre a cadência frígia vale relembrar a herança modal (somando-se ao uso citado a respeito dos termos autêntica e plagal) implícita nessa nomenclatura. As finalizações de frase sobre os distintos modos, geralmente, compreendiam a progressão indo do intervalo terça para uníssono ou de sexta para a oitava (vide Ex.5). Dentre essas sucessões, a única que continha naturalmente (sem alteração cromática) o movimento de semitom $(F-E)$ na voz inferior era aquela pertencente ao modo frígio, pois nos outros modos a voz inferior realiza um movimento intervalar de segunda maior $(E-D, G-F$ e $A-G$ ). Como a sucessão característica do modo frígio é similar ao movimento da subdominante em primeira inversão para a dominante (iv6 - V) nas tonalidades menores (por exemplo: em Am: $D m / F-E 7$ ), os autores mantiveram o rótulo original, denominando, então, essa progressão como cadência frígia. 0 emprego dessa progressão é mais observado para finalizações de frases em seções centrais da peça (ver Ex.6a); todavia, passou a ser aplicada para cadências mais conclusivas ou mesmo para o término de movimentos internos de uma obra (ver Ex.6b). Assim, a cadência designada até hoje como frígia remete ao uso modal referindo-se aos movimentos de segunda menor na voz inferior (baixo) e segunda maior na voz superior (melodia).

\section{3 - Conclusões}

Sobre a questão da classificação das cadênciasé necessário, de saída, perguntar qual a relevância ou justificativa para a inclusão desse tópico no currículo das disciplinas como harmonia, teoria ou análise musicais. Poder-seia questionar a relevância do estudo desse assunto em vista do mesmo não fazer parte da prática composicional contemporânea, composta majoritariamente de obras não tonais. No entanto, é preciso ressaltar que a formação do instrumentista, bem como a quase totalidade do repertório atual de concerto, compõem-se de obras do período da prática comum, donde se observa o emprego das citadas cadências. Além disso, muitos compositores a partir do século XX fizeram renovações de procedimentos tradicionais. Consequentemente,

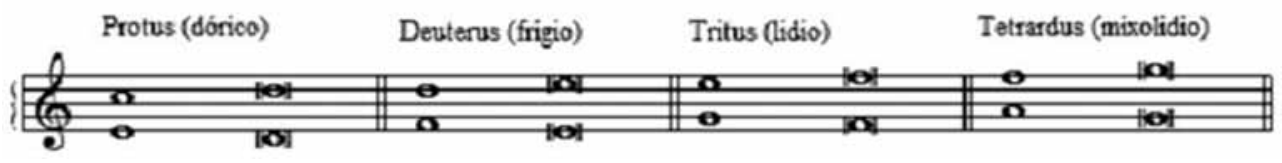

Ex.5 - Resoluções nos modos autênticos.
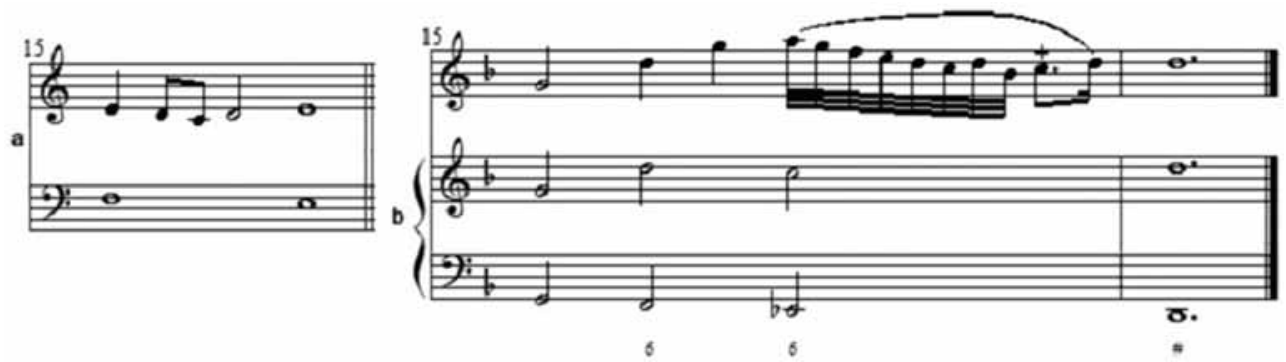

Ex.6 - Empregos da cadência frígia. (a) Orlando di Lasso, Oculus non vidit (comp. 15). (b) Arcangelo Corelli, Adagio da Sonata $0 p .5 n^{\circ} 5$, para violino e contínuo (c.15-16). 
o entendimento dos artifícios técnicos tradicionais é imprescindivel tanto para a compreensão dessas obras, quanto das reformulações que os mesmos procedimentos receberam na modernidade. Ainda, preservando a ideia de cadência enquanto momento de finalização de frases ou de distensão será possivel transferi-la para o âmbito não tonal, verificando os procedimentos usados pelos compositores para pontuação do discurso musical e da maneira como oferecem desfechos frasais sem valer-se das progressões tradicionais.

Ao lado desses aspectos relacionados à atualidade do assunto, outro ponto a considerar-se sobre o estudo das cadências diz respeito à atividade analítica necessária para o entendimento da obra que, por sua vez, permite ser usada para embasar as opções interpretativas, servir como ferramenta composicional e contribuir para a formação global do músico. Ao debruçar-se sobre o estudo de uma música, uma das tarefas é determinar as partes ou seções em que a mesma encontra-se estruturada. Um dos procedimentos para realizar essa divisão é a discriminação de fenômenos estruturais. E dentre os fenômenos importantes para balizar essa segmentação está a observação de progressões cadenciais, que servem como guias nessa tarefa de interpretação sintática da obra. A segmentação da obra em partes (frases, períodos, seções) propicia organizar as ideias musicais viabilizando, assim, seu entendimento, ou seja, a compreensão da ordem tonal de modo a conseguir efetivar a relação entre os diversos elementos da composição.

0 que poderia ser passível de contestação é a denominação utilizada na identificação das respectivas cadências, posto que esses rótulos são de pouca relevância para a compreensão da peça. Schoenberg já pontuava trataremse, essas designações, apenas de "nomes, expressões técnicas que nada dizem quanto à significação harmônica dessas cadências" (SCHOENBERG, 2001, p.207). Impingir um rótulo à determinada progressão pode, no lugar de ajudar, trazer confusão na medida em que gera um acúmulo tautológico de informação. Uma análise crua irá mostrar que as designações 'cadência perfeita' e 'cadência imperfeita' subentendem a existência da perfeição e, consequentemente, da imperfeição em música, o que faz pensar se um compositor pretenderia, conscientemente, construir algo imperfeito (sinônimo de errado). Nomear cadências do tipo V-vi (ou V-16) como 'interrompida' ou 'evitada' significa que a mesma foi abortada, ou seja, não se concretizou. Todavia, acompanhando o movimento cadencial nota-se que de fato a mesma realizou-se, pois houve a finalização de frase (embora, não da maneira esperada), assim, esses termos revelam-se inapropriados. A designação 'cadência composta' implica na existência da simples, bem como, 'completa', subentende serem as demais (inclusive a autêntica) incompletas, o que no mínimo é engraçado, pois como uma coisa é perfeita e incompleta ao mesmo tempo? Semi-cadência também se mostra como um termo equivocado, pois 'semi' significa metade (como em semicírculo, semibreve, semitom), o que indicaria uma progressão acórdica realizada pela metade. No entanto, uma frase concluída com a sequência $V / V-V$ me parece completa, denotando a intenção do compositor em finalizar no quinto grau.

Alguns autores já sugeriram outras maneiras de classificar as cadências, observando a continuidade, ou não, dessas progressões. Sépe, como citado, propôs a nomenclatura conclusiva e suspensiva; em Kostka \& Payne (veja 2000, p.161) há a proposta de conclusivas e progressivas. Igualmente, conclusivas e transitivas ou intermediárias são tentativas de analisar as cadências levando em conta se estas encerram ou se tendem a continuar para uma próxima parte da música. Schoenberg, também, sugeriu dois grandes grupos para classificação das 'conclusões' (veja 2001, p.428-432) que, sumariamente, poderiam ser descritos como: 'autêntico' e 'não autêntico'. As conclusões autênticas valem-se das progressões: IV-V-I, II-V-I e VI-V-I. Todas as demais sucessões pertencem ao segundo grupo. As terminações desses dois grupos dividem-se em 'completas' e 'meias-cadências'. As progressões só são consideradas 'completas' quando: conduzem à tônica, valem-se apenas de notas próprias da escala e os acordes I e V estão no estado fundamental. As meias-cadências possuem subdivisões de acordo com o uso ou não de notas estranhas à escala da tonalidade para a qual conduzem. Assim, são chamadas de 'inexatas' (quando são usadas exclusiva ou parcialmente notas da escala) e 'exatas' (tratando-se os respectivos graus conforme tonalidades secundárias). De modo resumido é possivel montar o seguinte esquema a partir da classificação de Schoenberg:

$\left.\begin{array}{|l}\text { I - AUTÊNTICAS } \\ \text { II - NÃO AUTÊNTICAS }\end{array}\right\}\left\{\begin{array}{l}\text { 1) Completas } \\ \text { 2) Meia-cadência }\end{array}\left\{\begin{array}{l}\text { a) Inexatas } \\ \text { uso parcial de notas estranhas à escala } \\ \text { b) Exatas }\end{array}\right.\right.$


Essas propostas classificatórias, ao dividirem em dois grupos as cadências, me parecem oferecer uma maneira clara e concisa para se pensar os diversos tipos de finalização das frases musicais, permitindo inclusive um uso atualizado no repertório pós-tonal (vide adiante). Os títulos adotados para os respectivos grupos ainda serão passíveis de contestação, já que 'progressiva' pode trazer a ideia de sua contraparte 'regressiva' denotando (ao menos em português) a antítese 'progressista' versus 'reacionário'. Igualmente, 'suspensiva' implica deixar algo em suspenso, não resolvido, e como já comentado, desfechos desse tipo concluem de fato as frases, pois oferecem um sentido terminação às mesmas; aspecto este que irá desdobrar-se para a classificação 'conclusiva', uma vez que toda cadência pode possuir sensação de fechamento. Todavia, alguma nomenclatura terá de ser adotada e uma vez que a divisão em dois grandes grupos, como proposta pelos autores citados, traz subentendida uma avaliação do caráter de maior ou menor força cadencial poder-se-ia pensar em valer-se de termos que aludam a essa característica. Schoenberg em algumas passagens refere-se a esse aspecto ao comentar sobre conclusões 'enérgicas' (veja 2001, p.428). Já imbuido de seu princípio da monotonalidade, ele entendia as progressões enérgicas como conclusões, enquanto as demais tratarse-iam de momentos de paradas em meio ao fluxo musical: "parar não é concluir. Parar constitui-se em algo simples: não continuar. Concluir, entretanto, é outra coisa" (SCHOENBERG, 2001, p.195). Inclusive, por essa maneira de pensar, Schoenberg classificava a cadência plagal e algumas cadências à tônica dentre as semi-cadências (veja 2001, p.230), já que pressupunham continuação.

Levando-se em conta a 'força' dos desfechos fraseológicos, que apresentam desdobramentos no plano da interpretação, poderia sugerir tratar as cadências como contundentes e amenas. Nesse sentido, lembrando que o mais importante é identificar a ocorrência ou não de uma cadência (já que nem toda sucessão V-I implica em cadência - ver adiante), será necessário considerar os fatores que concorrem para uma sensação mais contundente de conclusão. Desse modo, nas progressões cadenciais deve ser observado nos acordes envolvidos: presença da fundamental, inversões, relação de quintas, presença da sensível, presença do trítono, adição de outras tensões $\left(9^{\text {a }}, 11^{\text {a }}\right.$, etc.), uso de apojaturas ou retardos e 0 acorde que conclui a cadência (de modo a verificar a quebra de expectativa).

Observam-se no Ex.7 diversas sucessões V-I (neste caso, os acordes (7- $F$ ), porém, dentre essas a única sucessão que implica em uma conclusão é a última. Note-se que a sensação cadencial não se constrói apenas com acordes, mas principalmente pelo perfil melódico e pela estrutura rítmica (neste caso realizando uma hemíola compassos 20 e 21 do Ex.7), também associada a aspectos dinâmicos. Neste período, construído de duas frases de quatro compassos cada, percebe-se um senso conclusivo mais contundente na segunda frase justamente pela convergência de todos esses fatores. Embora o final da primeira frase contenha a sensivel da nota $C$, a harmonia subentende $F$ (tônica desse período) gerando uma ambiguidade; além disso, não há mudança no movimento rítmico e a finalização ocorre de maneira não esperada (já que a sensivel implicaria uma resolução no acorde de $C$, mas escuta-se $A m$ ). Com isso, não há na primeira frase um desfecho, mas sim a manutenção da tensão que só será desfeita com a cadência da segunda frase. Donde se percebe que o sentido de conclusão é amenizado na primeira frase e contundente na segunda (embora nesta frase o acorde de dominante apareça sem sua terça, sensivel de $F$, mas contenha a $7^{\text {a)}}$.

A importância do fator "ritmo" é contumaz para a sensação de resolução das frases, aspecto demonstrado nos próximos exemplos. 0 Ex.8 traz o final de uma obra para coro e piano de Mendelssonhn donde se pode notar a conclusão em uma cadência plagal $(G-D)$; todavia, observa-se que essa resolução, por si menos enfática (já
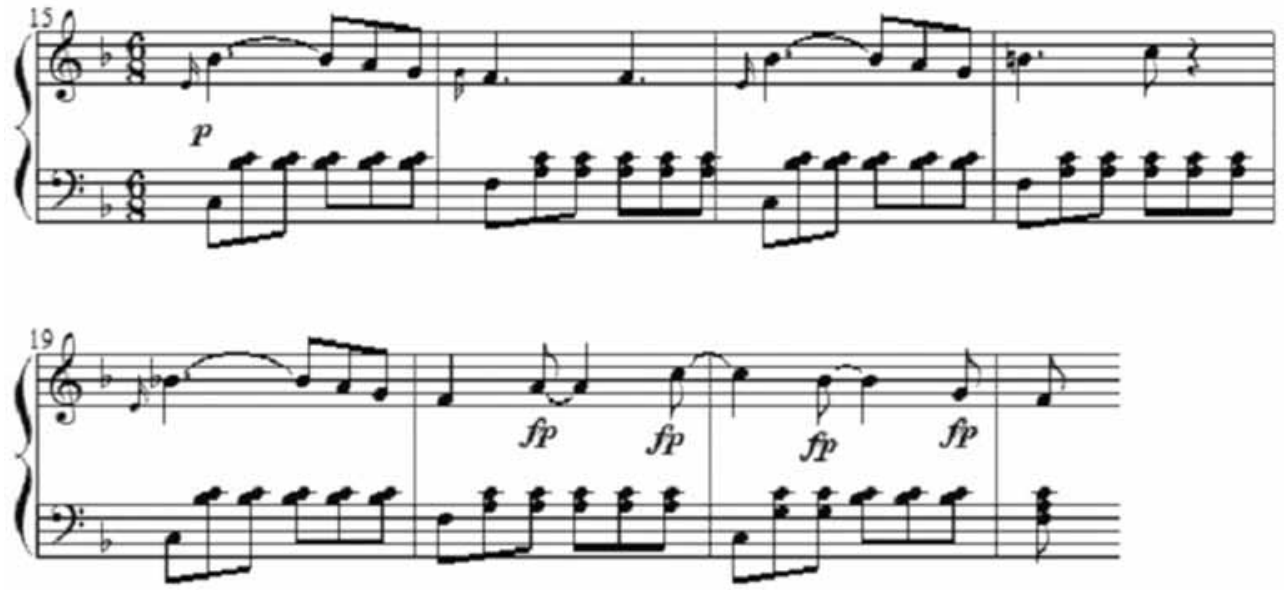

Ex.7 - Mozart: Sonata K.332, III (c.15-22). Sucessões V-I não cadenciais. Resolução das duas frases de maneiras distintas. 
que não contém elementos de instabilidade como trítono e sensivel), é intensificada pelo acréscimo de alguns fatores: adição da nota Esobre o acorde de $G$ (compasso 40 do Ex.8) direcionando o perfil melódico ao repouso sobre uma nota da tônica $(F \#)$ refreando a atividade rítmica; além disso, há o retardo da apresentação da terça do acorde da tônica (penúltimo compasso), em uma espécie de apojatura G-F\#, perfazendo, a seguir, o movimento melódico similar ao compasso precedente $E-F \#$, novamente resolvendo na terça do acorde. É evidente a desaceleração rítmica (partindo de semi-colcheias para semibreve). Desse modo, a sucessão amena IV - I é tornada mais contundente e, consequentemente, mais conclusiva.
Diferentemente, o uso da sucessão plagal no final de frase do Ex.9, embora conclusivo, é mais ameno que o mostrado no Ex.8, pois os aspectos rítmicos e melódicos não confluem sincronicamente, ou seja, é mantida a mesma movimentação rítmica da linha melódica, cujo desfecho se dá após a progressão harmônica. Assim, Debussy evita uma resolução mais enérgica e preserva 0 caráter suave e delicado deste prelúdio.

A eficácia da estruturação rítmica é também mostrada no próximo trecho (Ex.10), final do Concerto para Orquestra de Cordas e Percussão de Guarnieri. A peça é finalizada sobre o acorde de $D$, porém, não há uso do acorde de

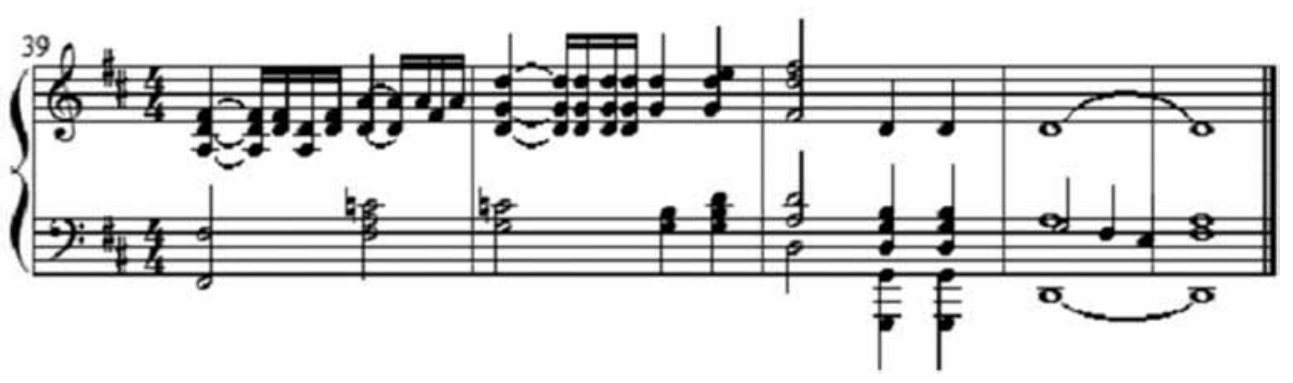

Ex.8 - Felix Mendelssohn: Saint Paul, Op.36, №16, c.39-43, parte do piano.

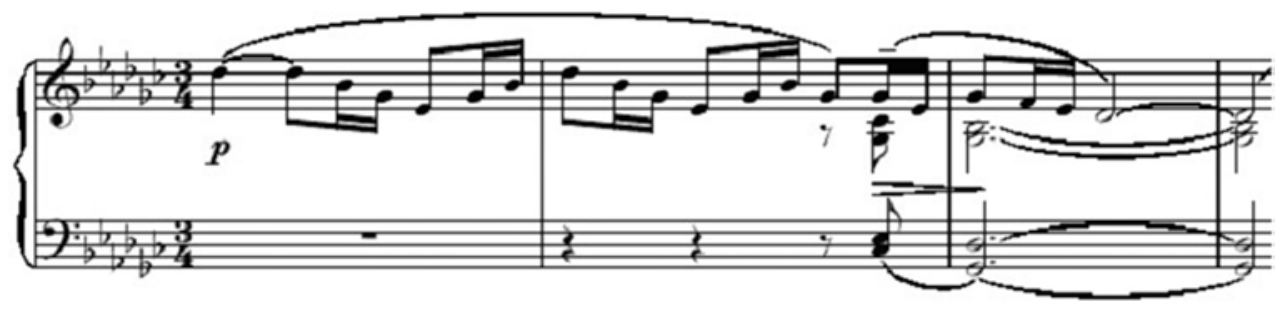

Ex.9 - Claude Debussy: La Fille aux Cheveux de Lin, c.1-4.

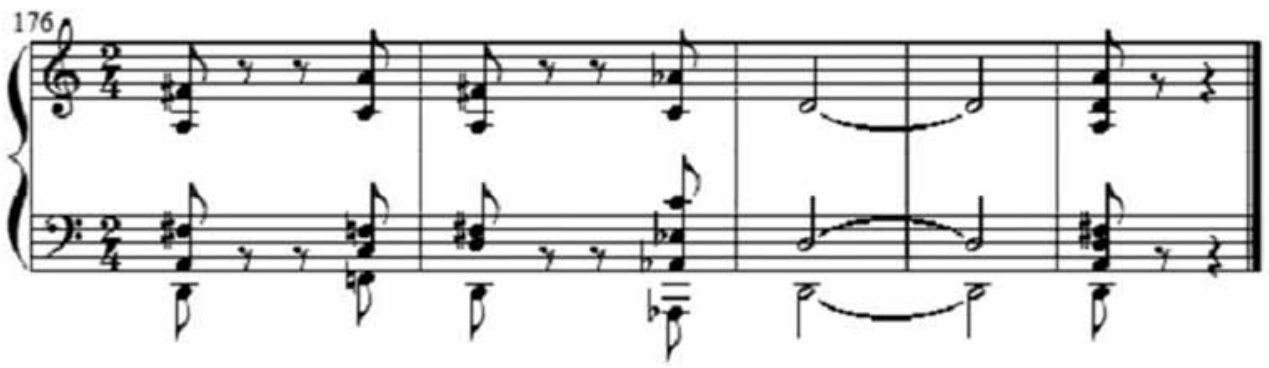

Ex.10 - Camargo Guarnieri: Concerto para Orquestra de Cordas e Percussão, c.176-180, redução das partes de viola, cello e baixo 
dominante. No lugar desta, o compositor emprega um acorde distando da tônica $(D)$ uma quinta diminuta $(A b)$. Como o impulso rítmico é forte e característico de desfechos fraseológicos, a sensação conclusiva é satisfeita, mesmo na ausência de funções tradicionalmente mais resolutivas, como dominante ou mesmo subdominante.

Uma sequência inusitada de acordes sem relações tonais é mostrada na finalização da frase inicialmente modal de outro prelúdio de Debussy. Embora os acordes usados para concluir a frase $(E b-A b-G b)$ remetam para algo bem distinto do campo harmônico exposto nos primeiros compassos, a diminuição da intensidade e o refreamento do andamento concorrem para conferir um sentido de desfecho à frase, mesmo com a mudança súbita da "ambiência" harmônica (Ex.11). Neste mesmo prelúdio, uma outra sucessão inusitada de acordes ocorre no final de uma seção, conduzindo a uma nova parte centrada em C. Embora os acordes pareçam não obedecer a relações para com um centro tonal determinado (sucessão $E m-A$ - Fm - C), pelo fato dos dois últimos acordes envolvidos implicarem uma cadência plagal, mas com a subdominante menor (iv-l), associada à diminuição do andamento, a sensação de finalização é preservada (ver Ex.12).
Em certo sentido, os exemplos anteriores já indicam que resoluções cadênciais são possíveis mesmo na ausência da tonalidade, já que o senso conclusivo traz implícito a convergência de outros fatores musicais. Nos próximos casos apresentados, essas características serão reforçadas. Os Ex.13 e 14 são extraídos da canção Dem Schmerz sein Recht de Alban Berg. Note-se que a estrutura fraseológica do texto do poema governa a construção da música de modo a gerar concomitância entre as partes do canto e do acompanhamento (não tão explícitos nos exemplos de Webern mostrados posteriormente). Todavia, mesmo na ausência do texto, a segmentação das frases desta primeira parte da peça é facultada observando-se os agregados acórdicos utilizados por Berg. Os primeiros quatro compassos funcionam como introdução, promovendo um aumento de densidade em uma nota $D$ pedal. 0 compasso cinco mostra a principal entidade harmônica desta peça, o agregado $D-A-F \#-C-F$. Por meio deste, é possível entender que os compassos oito e nove marcam o final da primeira frase, tratandose de uma espécie de extensão cadencial realizada sobre esse referido agregado. No compasso sete, uma formação harmônica toniciza o agregado principal com intervalos de semitons (Eb-G-C\#-F\#), formação que reaparece no

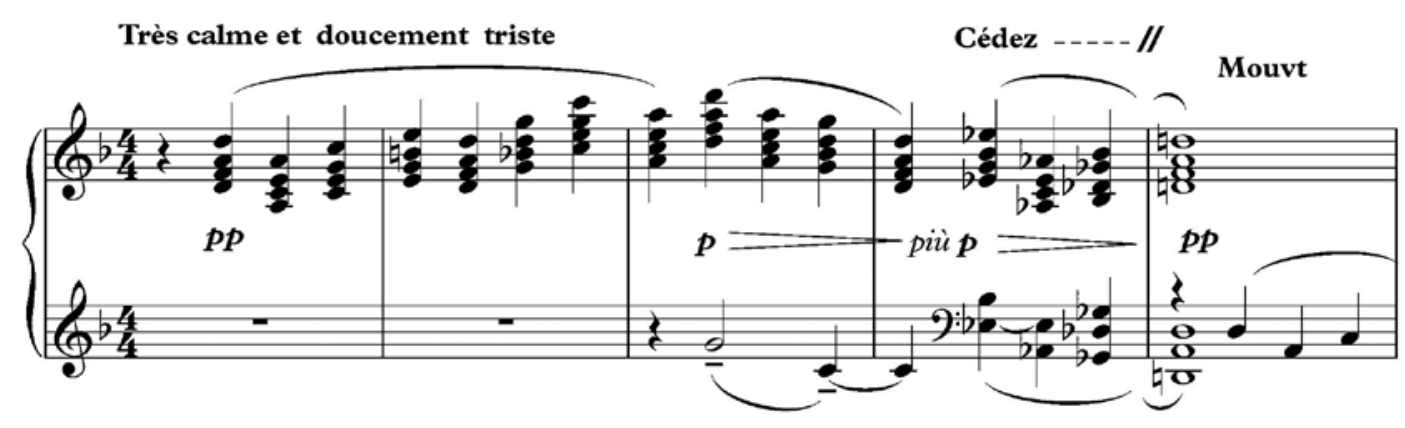

Ex.11- Claude Debussy: Canope, c.1-5.

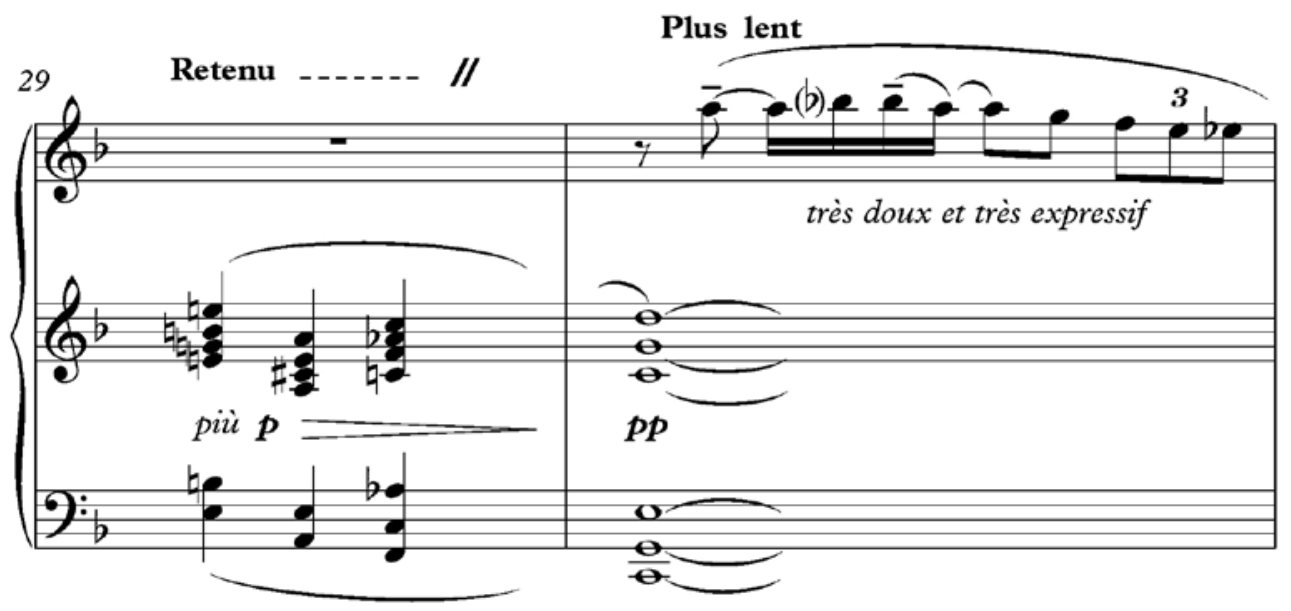

Ex.12 - Claude Debussy: Canope, c.29-30. 

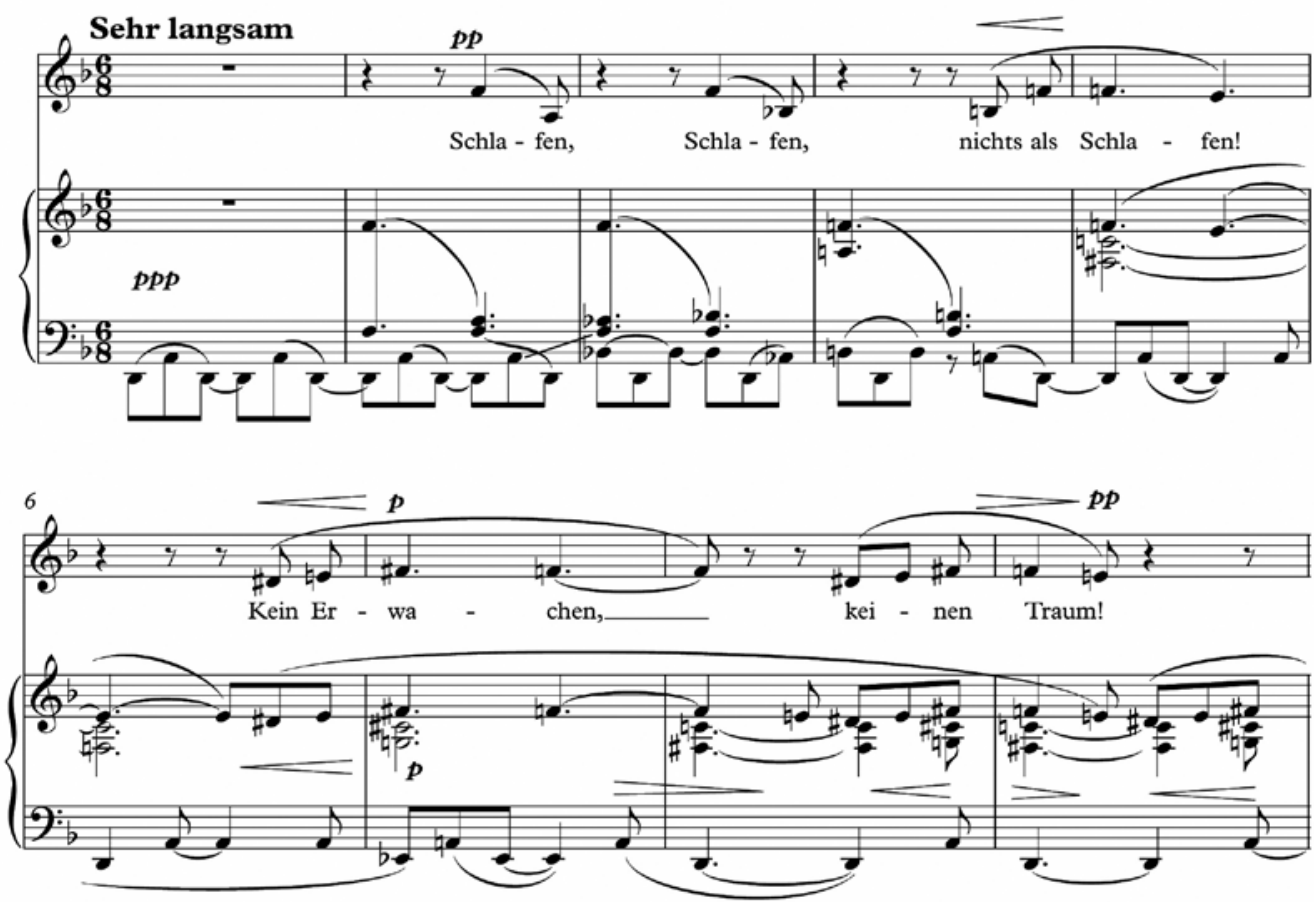

Ex.13- Alban Berg: Dem Schmerz sein Recht, Op.2, no 1, c.1-9.
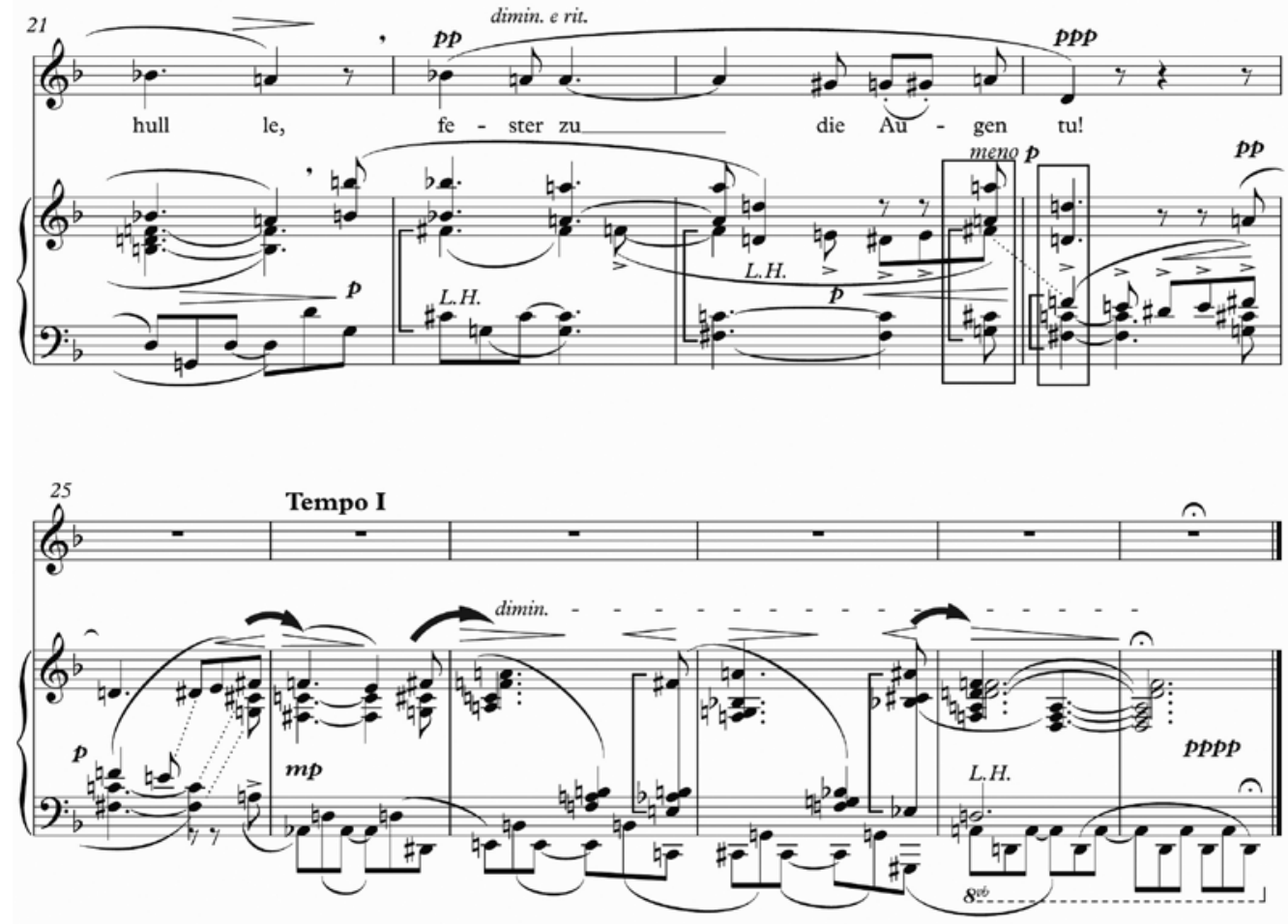

Ex.14 - Alban Berg: Dem Schmerz sein Recht, 0p.2, no 1, c.21-30. 
final do compasso oito substituindo, porém, o movimento de sensivel superior $(E b-D)$ para uma relação de quintas $(A-D)$, tornando o desfecho da frase mais contundente. 0 Ex.14 mostra os compassos finais desta peça. Novamente, dá-se o mesmo tipo de tonicização a partir do compasso 22, mas o agregado principal está invertido (nota F\# no baixo), aparecendo em posição fundamental somente nos dois últimos compassos da obra. Vale também notar a sequência de tonicizações na linha do baixo a partir do compasso $26 D \#-E, C-C \#, G \#-A$, permeada pela sucessão de tritonos $A b-D, B-F, G-E b$, aspectos que confluem para intensificar o sentido de resolução na chegada do último acorde $(D m)$ resolvendo o conflito maior menor.

Esse mesmo tipo de tonicização pode ser verificado nos trechos seguintes extraídos de canções do 0pus 4 de Webern. 0 primeiro número inicia-se apresentando ao piano o agregado sonoro E-G\#-C\#-F. Esse mesmo agregado finaliza a segunda frase, compasso 3, tonicizado pelo agregado $F-C-E-F \#-B-E b$. A nota $E$ é comum a ambos agregados, sendo então mantida.
As três notas superiores, por sua vez, realizam um movimento de segunda maior ascendente em direção às respectivas notas do primeiro agregado, enquanto as notas graves $(F$ e $C$ ) resolvem por semitom descendente. Assim, o agregado inicial é tonicizado de modo ascendente e descendente, concomitantemente a um ritenuto e uma ligeira diminuição da intensidade. Note-se que diferentemente do exemplo de BERG, a parte do piano, embora claramente uma parte de acompanhamento, possui uma maior independência em relação à linha do canto, porém, ambas cadenciam em acordo com a estrutura do texto.

0 mesmo tipo de finalização tonicizando um agregado por meio de tons e semitons em sentido contrário pode ser observado nas canções de número II e III deste mesmo Opus. Na terceira canção, Ex.16, a parte superior do agregado sonoro $G-B-E-B-D \#-G \#$ é tonicizada por movimento ascendente de segunda maior ( $A-C \#-F \#)$, enquanto a parte inferior desse agregado é tonicizada por semitom descendente $(A b-C-F)$.

\section{EINGANG}

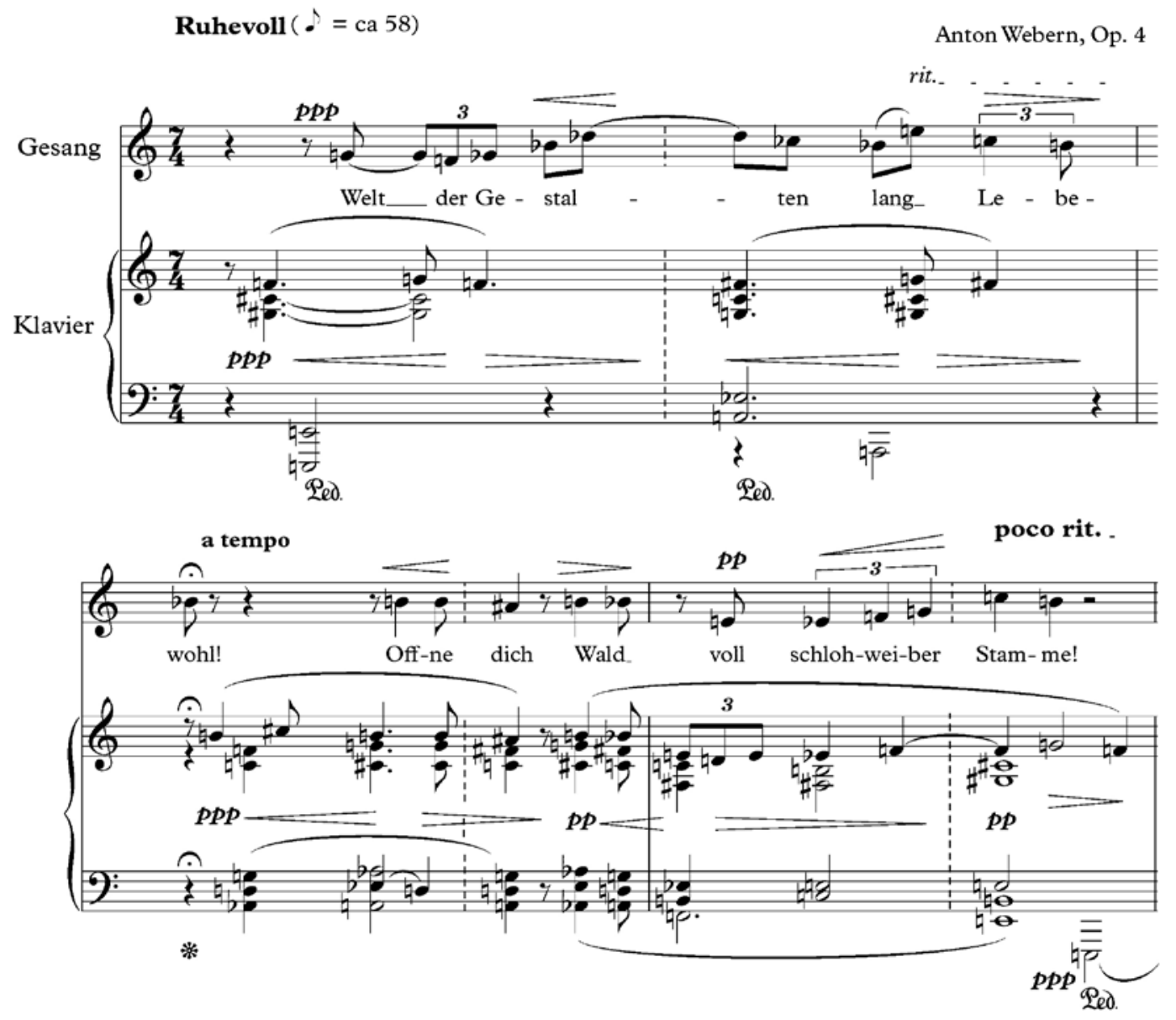

Ex.15 - Anton Webern: Fünf Lieder, 0p.4, I, c.1-3. 


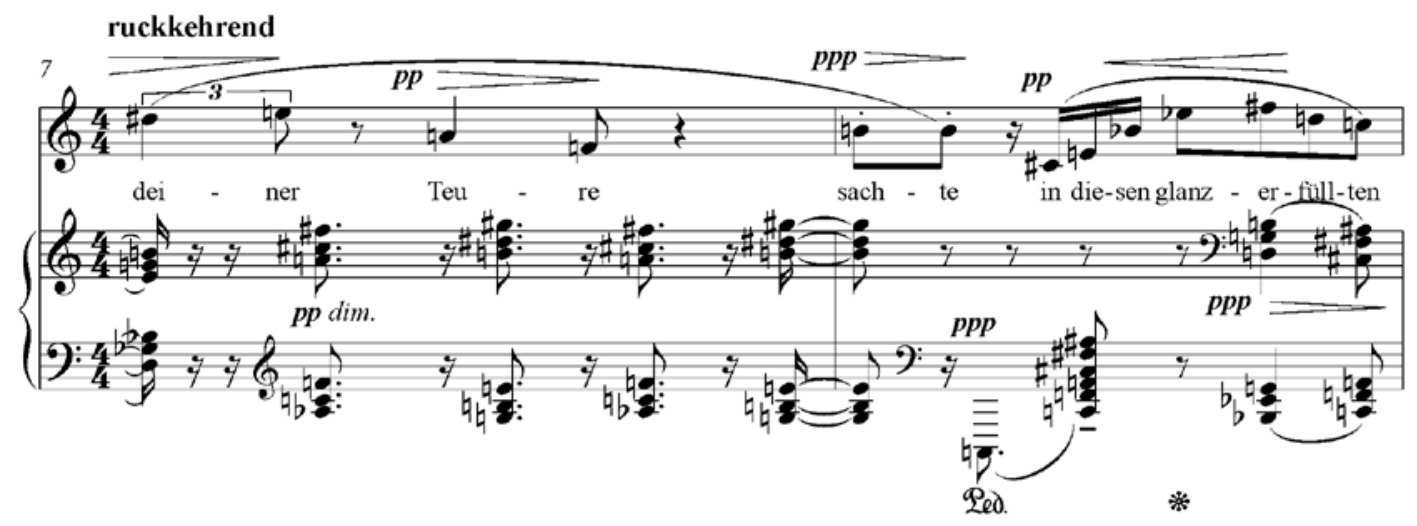

Ex.16 - Anton Webern: Fünf Lieder, Op.4, III, c.7-8.

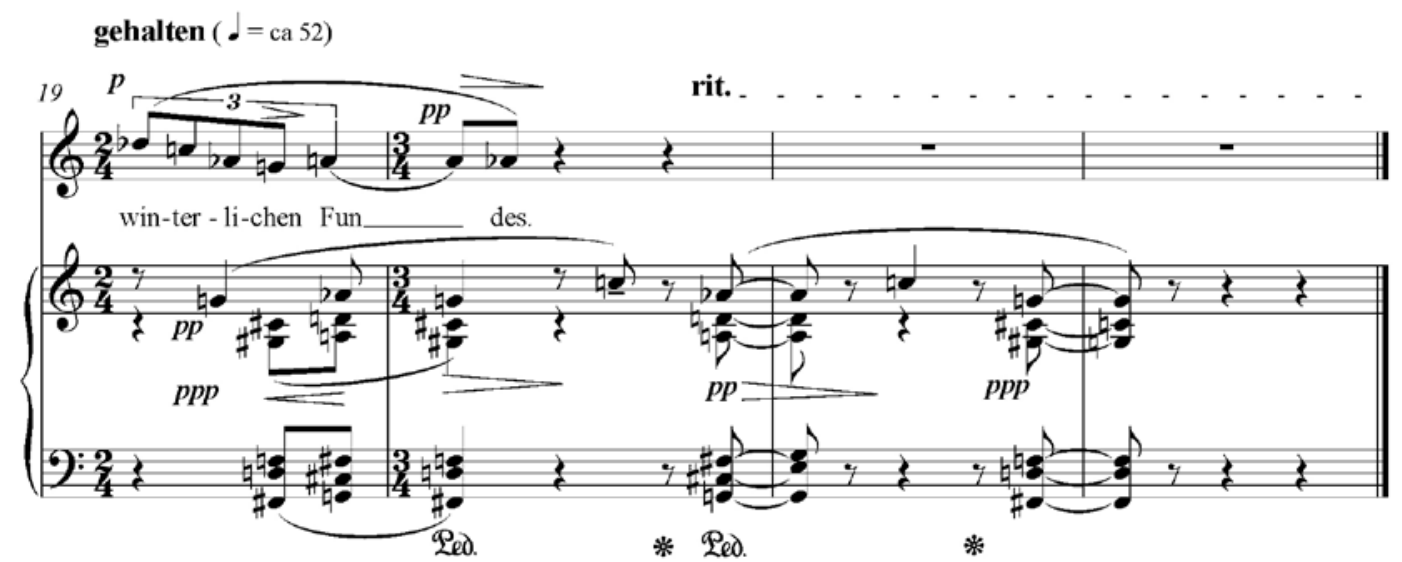

Ex.17 - Anton Webern: Fünf Lieder, Op.4, II, c.19-22.

No Ex.17, o desfecho da frase se dá sobre o agregado $F \#-D-F-G \#-C \#-G$, este, por sua vez, tonicizado na parte superior por semitom descendente $(A-D-A b)$. Na parte mais grave do agregado, no entanto, há a mistura de movimentos ascendentes e descendentes, porém, todos caminham por semitom em direção ao agregado harmônico que conclui a frase.

Esses exemplos indicam que o conceito de cadência, ou de função cadencial, enquanto remeta ao sentido de resolução fraseológica, pode ser verificado em quaisquer tipos de repertórios, variando, obviamente, de acordo com a estética do período, porém, preservando sua função original. Ressaltese, mais uma vez, que finalizações não dizem respeito somente aos aspectos harmônicos, mas estão atreladas aos demais fatores musicais, implicando, geralmente, em desaceleração rítmica e diminuição da intensidade.
Pelo exposto, é possivel deduzir que seria bem-vinda uma reunião de estudiosos e teóricos da música com o objetivo de promover uma revisão dos conceitos, entendimentos e nomenclaturas adotadas no Brasil e, eventualmente, a proposta de uma unificação terminológica para a área de Teoria e Análise musicais. Da mesma maneira como o conceito de dissonância foi revisto e relativizado à luz do repertório pós-tonal, a ideia de função cadencial também pode ser repensada de modo a abarcar características do repertório não tonal. Neste artigo tratou-se especificamente do conceito de cadência, todavia, outros tantos tópicos poderiam ser mais bem discutidos por musicólogos, estudiosos e teóricos afins, pois certo consenso beneficiaria todas as áreas relacionadas à pesquisa, ensino e prática musicais. 


\section{Referências}

BENEDICTIS, Savino de. Terminologia Musical. São Paulo: Ricordi, 1970.

BENNET, Roy. Forma e Estrutura na Música. Trad. Luiz C. Csëko. Rio de Janeiro: Jorge Zahar, 1986.

BRISOLLA, Cyro M. Princípios de Harmonia Funcional. São Paulo: Novas Metas, 1979.

BRISOLLA, Cyro M. Princípios de Harmonia Funcional. Revisado e ampliado por Mario Ficarelli. São Paulo: Annablume, 2006. CARRETER, Fernando L. Diccionario de términos filológicos. Madrid: Editorial Gredos, 1973.

DANHAUSER, A. Théorie de la Musique. Paris : Editions Henry Lemoine, 1996.

DOUÉ, Jean. Étude Technique et Stylistique de L'Harmonie. Paris: Gérard Billaudot Ed., 2005.

GREEN, Douglass M. Form in Tonal Music. New York: Holt, Rinehart and Wiston, 1965.

HINDEMITH, P. Curso Condensado de Harmonia Tradicional. Trad. Souza Lima. São Paulo: Irmãos Vitale, s.d.

KOSTKA. Stefan \& PAYNE, Dorothy. Tonal Harmony. Boston: McGraw-Hill, 2000.

OLIVEIRA, José Zula de \& OLIVEIRA, Marilena de. Harmonia Funcional. São Paulo: Cultura Musical, 1978.

OWEN, Harold. Modal and Tonal Counterpoint. New York: Schirmer Books, 1992.

PERSICHETTI, Vincent. Twentyeth Century Harmony. New York, W. W. Norton, 1961.

PISTON, Walter. Armonía. Cooper City: Span Press Universitaria, 1998.

RAMEAU, Jean-Philippe. Treatise on Harmony. New York: Dover, 1971.

SCHOENBERG, Arnold. Harmonia. Trad. Marden Maluf. São Paulo, Edunesp, 2001.

SÉPE, João. Tratado de Harmonia. São Paulo: Ricordi Americana, 1942.

\section{Notas}

1 Essas e outras expressões cairam em desuso em razão da carga pejorativa, discriminatória e sexista que comportam. A esse respeito, a Society for Music Theory propôs uma normativa intitulada Guidelines for Nonsexist Language com intuito de suprimir o teor sexista implícito em certas nomenclaturas. Segundo essas orientações, os termos de uso corrente em textos sobre música que subentendam estereótipos machistas devem ser reformulados. Uma dentre as propostas sugeridas foi substituir a tradicional classificação de "cadência masculina" e "cadência feminina", respectivamente, para "terminação acentuada metricamente" e "cadência não acentuada metricamente". Sobre essas e outras diretrizes ver texto disponivel em www.wmich.edu/mus-theo/nsl.html

2 Verbete cadence disponivel em: www.britannica.com (consulta realizada em 23 de julho de 2009).

3 Na literatura espanhola, curiosamente, a palavra tonema é também usada no lugar de cadência. Alguns autores há tempos propunham a classificação de cinco classes de tonemas: tonema de cadencia (terminação grave, descenso da linha de entonação para um registro mais grave daquele ocorrido anteriormente no corpo da frase); tonema de anticadencia (inverso do tonema de cadencia, possui final tenso); tonema de semicadencia (terminação descendente, mas não tanto quanto a de cadencia); tonema de suspensión (a linha de entonação continua até o final, sem sofrer elevação ou descenso); tonema de semianticadencia (terminação menos alta que a de anticadencia). A esse respeito ver verbete "tonema" em Carreter, 1973, p.393.

4 Foi, também, nesse tratado em que pela primeira vez foi proposta a analogia entre uma linha melódica (nota, semi-frase e frase) e um verso poético (silaba, palavra, frase).

Antenor Ferreira Corrêa é professor adjunto do Departamento de Música da Universidade de Brasília. Autor do livro Estruturações Harmônicas Pós-tonais (Edunesp, 2006), do CD Veredas Sonoras (2010) e produtor do DVD Música Eletroacústica no Brasil (UNESP/TV UNICSUL, 2008). Percussionista, doutor em música pela Universidade de São Paulo (Bolsa CAPES, 2009), mestre em música pela UNESP (2004) e Bacharel em Composição e Regência pela UNESP (2001). Atualmente realiza pesquisa de pós-doutoramento junto ao Departamento de Antropologia da UnB. 